\title{
ЕМПТРИЧНА АНТИБАКТЕРІАЛЬНА ТЕРАПІЯ ІНФІКОВАНОГО НЕКРОТИЧНОГО ПАНКРЕАТИТУ В УМОВАХ АНТИБІОТИКОРЕЗИСТЕНТНОСТІ ЗБУДНИКІВ
}

\author{
О. І. Дронов¹, І. О. Ковальська ${ }^{1}$, А. І. Горлач ${ }^{1}$, К. О. Задорожна', В. В. Тинкалюк²,
}

С. С. Шаповал ${ }^{2}$, І. В. Сотнік ${ }^{2}$, І. А. Кучинська ${ }^{3}$

${ }^{1}$ Національний медичний університет імені О. О. Богомольця МОЗ України, м. Київ,

${ }^{2}$ Київський центр хірургії захворювань печінки, жовчних проток та підшлункової залози імені В. С. Земскова,

${ }^{3}$ Національна медична академія післядипломної освіти імені П.Л. Шупика МОЗ України, м. Київ

\section{EMPIRICAL ANTIBACTERIAL THERAPY OF INFECTED NECROTIC PANCREATITIS IN ENVIRONMENT OF ANTIBIOTICORESISTANCE OF CAUSATIVE AGENTS}

\author{
O. I. Dronov' ${ }^{1}$ I. O. Kovahlska ${ }^{1}$, A. I. Gorlach ${ }^{1}$, K. O. Zadorozhna ${ }^{1}$, V. V. Tynkalyuk ${ }^{2}$, \\ S. S. Shapoval' ${ }^{2}$ I. V. Sotnik ${ }^{2}$, I. A. Kuchynska ${ }^{3}$ \\ ${ }^{1}$ Bogomolets National Medical University, Kyiv, \\ ${ }^{2}$ Kyiv Centre of Surgery for Diseases of Liver, Biliary Ducts and Pancreas named after V. S. Zemskov, \\ ${ }^{3}$ Shupyk National Medical Academy of Postgraduate Education, Kyiv
}

\section{Реферат}

Мета. Розробити схему емпіричної антибактеріальної терапії (АБТ) у пацієнтів при інфікованому гострому некротичному панкреатиті (ГНП) на основі ретроспективного аналізу результатів бактеріологічного дослідження та вивчення антибіотикочутливості збудників.

Матеріали і методи. Проведений аналіз мікробного пейзажу пунктатів та виділень з дренажів з визначенням антибіотикочутливості та антибіотикорезистентності до антимікробних препаратів (АМП) у 52 хворих на інфрікований ГНП, яких лікували в клініці за період 2015 - 2016 р.

Результати. Мікробний пейзаж гострих парапанкреатичних та некротичних скупчень рідини за даними первинного дослідження в 82,7\% спостережень представлений моноінфекцією, у 17,3\% - асоціаціями грамнегативної мікрофрлори. Домінували Klebsiella pneumoniae (у 26,7\% спостережень), E. coli (у 21,7\%), Pseudomonas aeruginosa (y 17,4\%), Acinetobacter baumannii (y 12\%). Панрезистентна мікрофрлора виявлена у $33 \%$ спостережень, представлена Acinetobacter baumannii.

Висновки. На підставі ретроспективного аналізу ідентифікації збудників панкреатичної інфрекції та визначення їх антибіотикочутливості запропоновано схему емпіричної АБТ. Для терапії першої лінії рекомендуємо фторхінолони II покоління в поєднанні 3 протианаеробними препаратами, антибіотиками «резерву» вважаємо карбапенеми, уреїдопеніциліни з протианаеробними препаратами.

Ключові слова: панкреатична інфекція; емпірична антибактеріальна терапія; антибіотикорезистентність збудників.

Abstract

Objective. To elaborate the scheme of empirical antibacterial therapy (ABT) in patients in infected acute necrotic pancreatitis (ANP), basing on retrospective analysis of results of bacteriological investigation and studying of antibiotic sensitivity of causative agents.

Materials and methods. Analysis of microbial landscape of the puncture and excretions materials from drains with determination of antibiotic sensitivity and antibiotic resistance towards antimicrobial preparations (AMP) in 52 patients, suffering infected ANP, who were treated in the clinic for the 2015 - 2016 yrs period, was conducted.

Results. Microbial landscape of an acute parapancreatic and necrotic accumulations of liquid in accordance to data of primary investigation in $82.7 \%$ observations was presented by monoinfection, in $17.3 \%$ - by associations of gram-negative microflora. Klebsiella pneumoniae dominated (in $26.7 \%$ of observations), E. coli (in $21.7 \%$ ), Pseudomonas aeruginosa (in $17.4 \%$ ), Acinetobacter baumannii (in 12\%). Panresistant microflora were revealed in $33 \%$ observations and presented by Acinetobacter baumannii.

Conclusion. Basing on retrospective analysis of identification of the pancreatic infection causative agents and determination of their antibiotic sensitivity the scheme of empirical ABT was proposed. Fluoroquinolones of second generation in combination with antianaerobic preparations, carbapenems are considered the «reserved» antibiotics, ureidopenicillines with antianaerobic preparations are recommended as a first-line therapy.

Keywords: pancreatic infection; empirical antibacterial therapy; antibiotical resistance of causative agents.

Інфекційні ускладнення ГНП суттево впливають на прогноз захворювання, практично удвічі збільшують летальність [1]. Грамнегативні умовно патогенні мікроорганізми $€$ основними збудниками панкреатичної інфекції. У 2017 р. у Женеві ВООЗ виокремила «пріоритетні гру- пи патогенів», що характеризуються полірезистентністю, представляють найбільшу загрозу для людства: Acinetobacter, Pseudomonas, poдина Enterobacteriaceae (Esherichia coli, Klebsiella spp., Proteus spp.), стійкі до карбапенемів, синтезують $\beta$ лактамази розширеного спектру дії
[2]. Намагання запобігти інфікуванню вогнищ панкреатичного некрозу шляхом профілактичного призначення АМП не виправдалися [3]. У багатоцентрових дослідженнях доведено нездатність антибіотикопрофілактики позитивно вплинути на результат захворювання, відзначе- 
но збільшення частоти виявлення полірезистентних патогенних штамів $[4,5]$. Ефективність лікування інфікованого ГНП залежить, насамперед, від адекватної, не завжди одноетапної, санації вогнища інфекції [5]. В цьому аспекті АБТ має забезпечити контроль перебігу інфекційного процесу, попередження виникнення панкреатогенного сепсису [6]. Сьогодні профілактика та усунення генералізованих інфекційних ускладнень, з одного боку, та попередження формування мультирезистентної мікрофлори, з іншого, висувають вимоги до раціональної АБТ у пацієнтів за інфікованого ГНП [7]. Ідентифікація збудника панкреатичної інфекції дозволяє об'єктивізувати етіотропне лікування інфікованого панкреонекрозу. Необхідність призначення емпіричної АБТ виникає при контамінації мікроорганізмів (інвазивні втручання, біліарний панкреатит) або прогресуванні інфекційного процесу (прогресуючий синдром системної запальної відповіді, стійка «пізня» поліорганна недостатність). При емпіричному призначенні АМП потрібно зважати на специфіку й закономірності контамінації мікроорганізмів, здатність накопичуватись у достатній концентрації у підшлунковій залозі (Пз) [8, 9]. При виникненні суперінфекції необхідно завжди мати антибіотик «резерву», що може ефективно впливати на інфекційний процес.

Мета дослідження: розробити схему емпіричної АБТ у пацієнтів за інфікованого ГНП на основі ретроспективного аналізу результатів бактеріологічного дослідження та визначення антибіотикочутливості збудників.

\section{МАТЕРІАЛИ І МЕТОДИ ДОСЛІДЖЕННЯ}

Проведений аналіз мікробного пейзажу пунктатів та виділень 3 дренажів 3 визначенням антибіотикочутливості та антибіотикорезистентності до АМП у хворих за інфікованого ГНП, яких лікували в клініці за період 2015 - 2016 р. Обстежені 52 пацієнта, в тому числі 34 (65,4\%) чоловіка, 18 (34,6\%) жінок. Вік хворих від 25 до 73 років, у середньому $(43,2 \pm 13,6)$ року. В усіх пацієнтів відзначали гострий панкреатит середньої тяжкості та тяжкий, за шка-

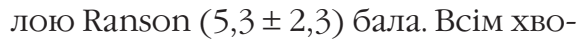
рим проведена АБТ: до ідентифікації збудника - емпірична, у подальшому - $з$ огляду на його антибіотикочутливість. Бактеріологічні дослідження проводили через кожні 3 - 4 доби. Виконані 258 бактеріологічних досліджень клінічного матеріалу, проаналізовані 12 мікробних штамів. Тривалість лікування хворих у стаціонарі становила у середньому $(32,72 \pm 17,27)$ доби, АБТ - $(23,34 \pm$ 12,24) доби.

Бактеріологічне дослідження передбачало посів матеріалу на живильні середовища 3 метою отримання чистої культури та визначення концентрації мікроорганізмів. Критерієм етіологічної значущості збудників, виділених 3 біологічних матеріалів, вважали $10^{5}$ колонієутворювальних одиниць (КУО) в 1 мл і більше. Оцінювали чутливість мікрофлори до АМП: ампіциліну, тетрацикліну, цефазоліну, цефтазидиму, цефуроксиму, цефтріаксону, цефоперазону, цефоперазону $з$ сульбактамом, цефепіму, кліндаміцину, ванкоміцину, азитроміцину, офлоксацину, ципрофлоксацину, левофлоксацину, лінезоліду, меронему, іміпенему, тигецикліну, фосфаміцину, гентаміцину, піперациліну з тазобактамом, колістину, азтреонаму, фузидину, фосфоміцину; якщо виявляли грибкову флору - до клотримазолу, флуконазолу, ітраконазолу, ністатину, амфотерицину.

Проаналізовані зміни мікробного пейзажу, що визначали під час повторних досліджень на тлі АБТ з огляду на спектр антибіотикорезистентності збудників.

\section{РЕЗУЛЬТАТИ}

Структура мікрофлори у пацієнтів за інфікованого ГНП представлена у табл. 1.

Ретроспективно оцінені види мікроорганізмів та їх метаморфози на тлі АБТ. Результати бактеріологічних досліджень свідчили, що мікробний пейзаж гострих парапанкреатичних та некротичних скупчень рідини за даними первинного дослідження у 82,7\% спостережень представлений моноінфекцією, у 17,3\% - асоціаціями грамнегативної мікрофлори. Всім пацієнтам з моменту верифікації інфекції та ідентифікації збудника проводили АБТ з огляду на чутливість збудника. За даними повторного дослідження біологічного матеріалу у 20,3\% спостережень відзначали зміну мікробного пейзажу, у 72,5\% наявність мікстінфекції, що у 79\% представлена асоціаціями грамнегативної мікрофлори, у 14\% - поєднанням грамнегативної та грампозитивної мікрофлори, у 7\% - грамнегативних мікроорганізмів та грибів.

Встановлено, що основними збудниками панкреатичної інфекції є грамнегативні мікроорганізми. Протягом останніх років спостерігають підвищення етіологічної значущості госпітальних штамів, що становлять 88,8\% в загальній структурі ідентифікованих збудників інфекціі. Домінували Klebsiella pneumoniae (у 26,7\% спостережень), E. coli (у $21,7 \%)$, Pseudomonas aeruginosa (y 17,4\%). Грампозитивна мікрофлора ідентифікована в 11,2\% спостережень, представлена S. aureus (у 3,9\%), E. faecium (у $5,8 \%$ ), S. saprophiticus (в 1,5\%); в 3,1\% - верифікована гриб-

\section{Таблиця 1. Характеристика мікрофлори, виявленої у пацієнтів} за інфікованого ГНП

\begin{tabular}{|lcc|}
\hline \multirow{2}{*}{ Мікроорганізм } & \multicolumn{2}{c|}{ Частота виявлення } \\
\cline { 2 - 3 } & абс & $\%$ \\
\hline Klebsiella pneumoniae & 69 & 26,8 \\
\hline Pseudomonas aeruginosa & 45 & 17,4 \\
\hline Escherichia coli & 56 & 21,7 \\
\hline Acinetobacter baumannii & 31 & 12 \\
\hline Enterococcus feacium & 15 & 5,8 \\
\hline Enterobacter aeruginosa & 8 & 3,1 \\
\hline Staphylococcus saprophiticus & 4 & 1,5 \\
\hline Staphylococcus aureus & 10 & 3,9 \\
\hline Proteus mirabilis & 4 & 1,6 \\
\hline Candida albicans & 8 & 3,1 \\
\hline Citrobacter diversus & 5 & 1,9 \\
\hline Morganella morganii & 3 & 1,2 \\
\hline Paзom ... & 258 & 100 \\
\hline
\end{tabular}


Таблиця 2. Характеристика антибіотикорезистентності основних збудників панкреатогенної інфекції

\begin{tabular}{|c|c|c|c|c|c|}
\hline \multirow[b]{2}{*}{ Антибіотики } & \multicolumn{5}{|c|}{ Частота антибіотикорезистентності збудника, \% } \\
\hline & $\begin{array}{c}\text { Klebsiella } \\
\text { pneumoniae }\end{array}$ & $\begin{array}{l}\text { Pseudomonas } \\
\text { aeruginosa }\end{array}$ & E. coli & $\begin{array}{l}\text { Acinetobacter } \\
\text { baumannii }\end{array}$ & $\begin{array}{l}\text { Enterococcus } \\
\text { faecium }\end{array}$ \\
\hline Меропенем & 17,1 & 73,8 & 20 & 77 & 92,3 \\
\hline Піперацилін/ тазобактам & 26 & 48,8 & 53,1 & 69 & 92,3 \\
\hline Амікацин & 53.2 & 55 & 43,9 & 84,5 & 100 \\
\hline Колістин & 43 & 33,8 & 59,5 & 57,3 & 100 \\
\hline Тайгециклін & 47,5 & 52,5 & 29,5 & 65,5 & 92,3 \\
\hline Цефоперазон /Сульбактам & 56,2 & 52,5 & 44,1 & 57,3 & 77 \\
\hline Ципрофлоксацин & 77 & 60 & 80,1 & 96,2 & 92,3 \\
\hline Левофлоксацин & 86 & 87,5 & 94,6 & 100 & 100 \\
\hline Тобраміцин & 92,8 & 78,8 & 79 & 65,5 & 100 \\
\hline Гентаміцин & 87,3 & 100 & 93,4 & 88,5 & 100 \\
\hline Цефтазидим & 92,1 & 72,5 & 84 & 88,5 & 100 \\
\hline Цефотаксим & 84,6 & 87,5 & 77,6 & 92,3 & 100 \\
\hline Цефтріаксон & 84,6 & 95 & 78,9 & 80 & 100 \\
\hline Цефепім & 95,8 & 80 & 93,4 & 96,2 & 100 \\
\hline Ампіцилін /сульбактам & 97,6 & 97,3 & 97,3 & 100 & 54 \\
\hline Ванкоміцин & 96,4 & 100 & 94,7 & 100 & 23,1 \\
\hline Доксициклін & 97,6 & 100 & 100 & 100 & 54 \\
\hline Лінезолід & 97,6 & 100 & 94,7 & 100 & 38,5 \\
\hline Кліндаміцин & 97,6 & 95 & 100 & 100 & 92,3 \\
\hline Азтреонам & 97,6 & 98,5 & 96 & 92,3 & 100 \\
\hline Фузидин & 97,6 & 100 & 94,7 & 100 & 48,1 \\
\hline
\end{tabular}

кова інфекція. Виділення при повторних дослідженнях антибіотикорезистентних штамів збудників свідчило про нозокоміальне інфікування вогнищ панкреатичного некрозу. 3 госпітальних штамів превалювали Acinetobacter baumannii (у 12\%), у 33\% резистентні до АМП. Антибіотикорезистентність основних мікроорганізмів, ідентифікованих у пацієнтів за інфікованого ГНП, наведена у табл. 2.

\section{ОБГОВОРЕННЯ}

При визначенні чутливості домінуючих збудників панкреатичної інфекції до АМП з широким спектром встановлено, що грамнегативні мікроорганізми були найбільш стійкими до цефалоспоринів III - IV покоління, напівсинтетичних пеніцилінів 3 інгібіторами бета-лактамаз, аміноглікозидів. Klebsiella pneumoniae резистентна до цефепіму, цефтазидиму, ампіциліну 3 сульбактамом, тобраміцину. Найбільш чутливим збудник був до меропенему, піперациліну/тазобактаму. Синьогнійна паличка нечутлива до цефтріаксону, цефотаксиму, гентаміцину, ампіциліну з сульбактамом. Максимальною чутливість Pseudomonas aeruginosa була до поліміксинів та антисиньогнійних пе- ніцилінів - колістину, піперациліну/тазобактаму. Представники сімейства Escherichia coli резистентні до цефепіму, гентаміцину, ампіциліну з сульбактамом, левофлоксацину. Найбільша чутливість кишкової палички відзначена до меропенему, тайгецикліну. У 7,7\% спостережень виявлена панрезистента мікрофлоpa, представлена Acinetobacter baumannii, 100\% штамів нечутливі до левофлоксацину, 96,2\% - ципрофлоксацину, 92,3\% - цефотаксиму, 96,2\% - цефепіму, 100\% - ампіциліну з сульбактамом. Чутливими до амікацину були 56,1\% штамів Acinetobacter baumannii, цефоперазону з сульбактом - 42,2\%, колістину - 42,7\%. Представники грампозитивної мікрофлори, що найчастіше виявляли у пацієнтів за інфікованого панкреонекрозу, також характеризувались полірезистентністю до більшості АМП широкого спектру дії. Enterococcus feacium був нечутливий до левофлоксацину, тобраміцину, гентаміцину, цефтазидиму, цефтріаксону, цефепіму, меропенему, піперациліну/тазобактаму. Найбільш чутливими ентерококи були до вузькоспецифічних АМП: тайгецикліну, ванкоміцину, лінезоліду. Слід відзначити, що 3 первинно ідентифікованих мікроорганізмів 54\% -ста- новили Klebsiella pneumoniae, 35\% Escherichia coli, 11\% - Pseudomonas aeruginosa. Всі первинно виділені штами збудників панкреатогенної інфекції були чутливі до цефоперазону з сульбактамом, ципрофлоксацину, амікацину, тобраміцину, меропенему, тайгецикліну. За даними динамічного бактеріологічного моніторингу відзначене формування резистентності збудників до АМП.

\section{ВИСНОВКИ}

1. Рання антибіотикопрофілактика не впливає на виникнення інфекційних ускладнень, звужує лікувальний спектр АМП, спричиняє формування резистентних штамів мікроорганізмів. Профілактичне застосування антибіотиків при асептичному некротичному панкреатиті не рекомендоване.

2. В етіології інфекційних ускладнень ГНП домінує грамнегативна мікрофлора (Klebsiella pneumoniae, Pseudomonas aeruginosa, Escherichia coli, Acinetobacter baumannii). Результати мікробіологічного моніторингу свідчать про високу резистентність грамнегативної мікрофлори до цефалоспоринів III покоління.

3. Показанням до призначення емпіричної АБТ є контамінація -застосування пункційно-дренуваль- 
них і лапароскопічних методів діагностики й лікування; ендоскопічна папілосфінктеротомія при біліарному панкреатиті.

4. При виборі АмП слід мати на увазі здатність накопичуватись в тканині ПЗ з забезпеченням оптимальної бактерицидної концентрації, а також ефективність щодо більшості

збудників панкреатичної інфекції.

5. Для першої лінії емпіричної АБТ рекомендуємо фторхінолони II покоління в поєднанні з протианаеробними препаратами, антибіотиками «резерву» вважаємо карбапенеми, уреїдопеніциліни 3 протианаеробними препаратами.
6. АБТ у пацієнтів при панкреатогенному сепсисі призначають на підставі аналізу результатів бактеріологічних досліджень $з$ динамічним мікробіологічним моніторингом через кожні 3 доби.

\section{ЛITEPATYPA/REFERENCES}

1. Werge M, Novovic S, Palle N, Gluud L. Infection increases mortality in necrotizing pancreatitis: A systematic review and meta-analysis. Pancreatology. 2016;16:698-707.

2. Villatoro $E$, Mulla M, Larvin M. Antibiotic therapy for prophylaxis against infection of pancreatic necrosis in acute pancreatitis. Cochrane Database of Systematic Reviews, 2010;5:53.

3. Antiboitic Guidelines 2015 - 2016. Treatment recommendations for adult inpatients Johns Hopkins medicine, 163.

4. Wittau M, Mayer B, Scheele J, et al. Systematic review and metaanalysis of antibiotic prophylaxis in severe acute pancreatitis. Scand J Gastroenterol. 2011;46(3):261-70.

5. Working Group IAP/APA Acute Pancreatitis Guidelines. IAP/APA evidence-based guidelines for the management of acute pancreatitis. Pancreatology. 2013;13:1-15.
6. Dronov AY, Kovalskaia YA, Lubenets TV, Kovalenko AP. Antybyotykoterapyia pry ostrom nekrotycheskom pankreatyte. Ukrainskyi zhurnal khirurhii. 2009;(1):164-5. [In Ukrainian].

7. Global priority list of antibiotic-resistant bacteria to guide research, discovery and development of new antibiotics. Geneva: World Health Organization; 2017:1-4.

8. De Campos T, Assef JC, Rasslan S. Questions about the use antibiotics in acute pancreatitis. World Journal of Emergency Surgery. 2006;20(1):1-6.

9. International Guidelines for Management of Severe Sepsis and Septic Shock 2013. Society of Critical Care Medicine, European Society of Intensive Care Medicine. 1 -8. 